\title{
EVALUASI KEBUTUHAN DAN KINERJA PELAYANAN ANGKUTAN UMUM PENUMPANG KOTA TASIKMALAYA
}

\author{
Sarah Mar'atusholihah ${ }^{1)}$ dan Abul Fida Ismaili ${ }^{1)}$ \\ 1) Jurusan Teknik Sipil Fakultas Sains dan Teknologi Universitas Teknologi Yogyakarta \\ Jl. Glagahsari No.63, Warungboto, Kec. Umbulharjo, Kota Yogyakarta, \\ Corresponding author : rarasarah521@gmail.com
}

\begin{abstract}
Abstrak
Pada masanya angkot digunakan masyarakat dalam menunjang kegiatannya sehari-hari namun permasalahan yang muncul pada saat ini, jumlah pengguna angkot mulai mengalami penurunan. Tujuan dari penelitian ini untuk mengetahui kinerja angkot dan tingkat kepuasan pelanggan terhadap angkot. Kinerja angkutan mengacu pada Pedoman Teknis Penyelenggaraan Angkutan Penumpang Umum di Wilayah Perkotaan dalam Trayek Tetap dan Teratur (Direktorat Jendral Perhubungan Darat 2002). Pendekatan IPA (Importance-Performance Analysis) dan Customer Satification Index (CSI) dilakukan ntuk mengetahui tingkat kesesuaian antara kepuasan dan kepentingan pengguna terhadap angkot. Hasil studi kinerja angkot pada tahun 2019, menunjukan kriteria angkot dalam kinerja yang baik dengan nilai rata-rata adalah faktor muat 29,75\%, kecepatan perjalanan $24 \mathrm{~km} / \mathrm{jam}$, waktu antara 3,4 menit, waktu perjalanan 2,875 menit/km, dan waktu tunggu 1,7 menit. Sedangkan untuk penilaian tingkat kepuasan pelanggan terhadap angkutan umum berdasarkan pendekatan IPA dan penilaian CSI masuk ke dalam kriteria Cukup Baik dengan nilai CSI yang diperoleh 55,56\% dalam range nilai $40 \%<55,56 \leq 60 \%$.
\end{abstract}

Kata kunci: Angkutan umum, Kinerja, IPA, CSI.

\begin{abstract}
Public transportation here plays a critical role in the development of a city as it is directly related to the distribution of goods, service and labours. The city transport was used by the community in supporting their daily activities but today it has emerged a problem regarding the decrease of the number of passengers. This research aimed to observe the performance of city transport and the level of satisfaction of the passengers to the city transport. The performance of city transport refers to the Technical Guidance of the Implementation of Public Transportation in Urban Areas in the Fixed and Regular Routes (Directorate General of Land Transportation 2002). To observe the level of concordance between satisfaction and interests of passengers towards public transportation, IPA (Importance-Performance Analysis) approach was used and Customer Satisfaction Index (CSI). The results of the study on the performance in 2019 showed that the city transport was in good criteria with an average value of a load factor of $29.75 \%$, traveling speed of $24 \mathrm{~km} / \mathrm{h}$, headway time of 3.4 minutes, trip time at 2,875 minutes $/ \mathrm{km}$, and waiting time for 1.7 minutes. Meanwhile, for a set of assessments of the customer satisfaction level with public transport based on the IPA approach and CSI assessment it was in Fairly Good criteria with a CSI value of $55.56 \%$ in the range of $40 \%<55.56 \leq 60 \%$.
\end{abstract}

Keywords: Public Transportation, Performance, IPA, CSI. 


\section{PENDAHULUAN}

Meningkatnya jumlah penduduk perlu diimbangi dengan peningkatan angkutan umum yang memadai. Peningkatan yang dimaksudkan bukan hanya peningkatan dalam aspek kuantitas, melainkan peningkatan akan kualitas angkutan umum yang sudah berjalan.Angkutan umum seharusnya berorientasi pada tingkat keamaan, kenyamanan dan ketersediaan agar dapat bersaing dengan angkutan pribadi. Menurut Morlok (1985), prioritas melaju di jalan seharusnya diberikan kepada angkutan publik, dan bukan kepada kendaraan pribadi. Prioritas tersebut dimaksudkan untuk mengangkut orang dalam jumlah besar dalam waktu singkat.

Namun pada kenyataanya, kendaraan pribadi yang terus meningkat menjadikan angkutan umum tidak lagi banyak diminati masyarakat.Dampak terhadap lalu lintas, terjadi peningkatan volume kendaraan yang menimbulkan kemacetan dan dapat menimbulakan polusi.Terdapat aspek negatif yang dirasakan pengguna angkutan umum berupa tidak adanya jadwal yang tetap, pola rute yang memaksa terjadinya transfer, kelebihan penumpang pada saat jam sibuk, mengemudikan kendaraan yang sembarangan dan membahayakan keselamatan dan kondisi internal dan eksternal yang buruk. Untuk menemukan solusi akan permasalahan yang terjadi, perlu adanya evaluasi terhadap kinerja angkot agar sesuai dengan standar minimum yang telah di tetapkan dalam keputusan Direktorat Jendral Perhubungan Darat tahun 2002.

Masyarakat sebagai calon penumpang angkutan umum memiliki peranan penting dalam mempertahankan eksistensi dan keberadaan angkutan umum. Kepuasan dan kepentingan penumpang menjadi faktor yang harus diutamakan dalam pelayanan angkutan umum.Analisis terhadap kepuasan penumpangpada penelitian ini dilakukan dengan menggunakan pendekatan Importance-Performance Analysis (IPA) dan Customer Satification Index (CSI).
Tujuan dari penelitian ini adalah untuk mengetahui kinerja angkot dan kebutuhan optimal angkot di Kota Tasikmalaya, mengetahui item-item yang dapat mempengaruhi kepuasan pelanggan dan mengetahui tingkat kepuasan masyarakat terhadap pelayanan angkot.

\section{METODE PENELITIAN Lokasi Penelitian}

Penelitian ini dilakukan di Kota Tasikmlaya, Jawa Barat, tepatnya arah perjalanan dari Terminal Pancasila ke Terminal Muncang Tasikmalaya. Penelitian ini dilakukan selama 5 hari pada pukul 05:00 hingga 18:00.

\section{Metode Pengumpulan Data}

Pengumpulan data dilakukan dengan melakukan survei statis, survei dinamis dan penyebaran kuesioner.Hasil survei yang didapatkan data primer berupa jumlah kendaraan, jumlah penumpang, waktu tempuh, frekuensi kendaraan dan penyebaran kuesioner. Data sekunder penelitian ini didapatkan dari instansi terkait yang meliputi peta jaringan jalan, rute angkutan, panjang rute jalan dan data-data lain yang dibutuhkan untuk melengkapi penelitian.

\section{Penentuan Sampel}

Data dari rata-rata jumlah penumpang harian angkutan umum digunakan dalam menentukan responden. Responden merupakan pengguna angkot dengan berbagai latar belakang yang berbeda,

\section{Metode Pengolahan Data}

\section{Analisis Kinerja Dan Kebutuhan Angkutan Umum}

Data hasil survei dianalisis berdasarkan "Pedoman Teknis Penyelenggaraan Angkutan Penumpang Umum di Wilayah Perkotaan Dalam Trayek Tetap dan Teratur Direktorat Jendral Perhubungan Darat Tahun 2002". 


\section{Uji Validitas dan Uji Reliabilitas}

Pengujian ini dilakukan dengan menggunakan bantuan aplikasi Microsoft Excel. Item pertanyaan dianggap "valid" apabila $r$ hitung $(+)>r$ tabel. Sedangkan item pertanyaan dianggap reliabilitas apabila $r>$ 0,6 . Apabila setiap item pertanyaan telah valid dan dianggap reliabilitas maka form kuesioner sudah dapat digunakan untuk melakukan pengujian.

\section{Analisis Tingkat Kepuasan Pelanggan}

Tahapan analisis tingkat kepuasan pelanggan:

a. Melakukan pendekatan IPA (ImportancePerformance Analysis) pada pendekatan IPA, penilaian dilakuakan dengan mempertimbangkan tingkat kepuasan pengguna dengan harapan pengguna terhadap angkutan umum. Analisa dilakukan dengan mencari harga kesesuaan (TKi) dan diagram kartesius. Dalam diagram kartesius terbagi menjadi empat bagian, yaitu:

1) Prioritas Utama = Unsur jasa yang dianggap sangat penting, namun manajemen belum melaksanakannya sesuai dengan keinginan pelanggan sehingga mengecewakan atau tidak puas.

2) Pertahankan Prestasi = Dianggap sangat penting dan sangat memuaskan, Untuk itu wajib dipertahankannya.

3) Prioritas Rendah = Pelaksanaannya oleh perusahaan biasa-biasa saja. Dianggap kurang penting dan kurang memuaskan.

4) Berlebihan = Dianggap kurang penting tetapi sangat memuaskan. (Supranto, 2006).

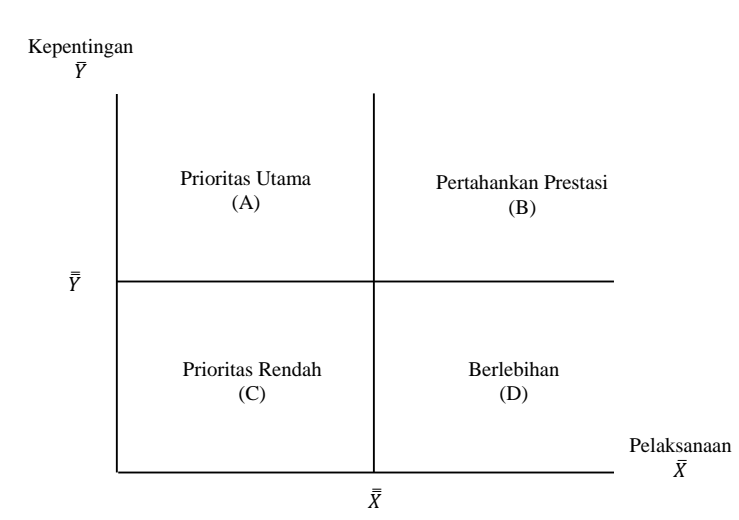

Gambar 1. Diagram Kartesius (Supranto, 2006)

a. CSI (Customer Satisfaction Index) Merupakan standar acuan yang digunakan untuk menyatakan baik dan buruknya kinerja angkutan umum.

Tabel 1.Rentang Skala Kepuasan Pelanggan

\begin{tabular}{|c|c|c|}
\hline No & Nilai $(\%)$ & Kriteria \\
\hline 1 & $80 \%<\mathrm{CSI} \leq 100 \%$ & Sangat Puas \\
\hline 2 & $60 \%<\mathrm{CSI} \leq 80 \%$ & Puas \\
\hline 3 & $40 \%<\mathrm{CSI} \leq 60 \%$ & Cukup Puas \\
\hline 4 & $20 \%<\mathrm{CSI} \leq 40 \%$ & Kurang Puas \\
\hline 5 & $0 \%<\mathrm{CSI} \leq 20 \%$ & Tidak Puas \\
\hline
\end{tabular}

\section{HASIL DAN PEMBAHASAN}

\section{Analisis Kinerja Angkutan}

Indikator yang didapatkan pada pengujian analisis kinerja angkutan, meliputi:

\section{Waktu tempuh}

Waktu tempuh adalah lama waktu yang dibutuhkan oleh suatu kendaraan untuk mencapai tujuan akhir perjalanan.Nilai waktu tempuh didapat dari survei dinamis.Waktu tempuh dapat dihitung dengan melakukan pengurangan antara jam berangkat angkutan dengan jam tiba angkutan. waktu tempuh yang tercatat pada penelitian ini dapat dilihat pada Tabel 2. 
Evaluasi Kebutuhan dan Kinerja Pelayanan Angkutan Umum Penumpang Kota Tasikmalaya

Tabel 2. Waktu Tempuh

\begin{tabular}{|c|c|c|c|c|c|c|c|}
\hline \multirow{5}{*}{ Tanggal } & \multirow{5}{*}{ Hari } & \multicolumn{3}{|c|}{ Waktu Tempuh (menit) } & \multicolumn{3}{|c|}{ Waktu Tempuh (menit) } \\
\hline & & Jam & Jam & Jam & Jam & Jam & Jam \\
\hline & & Sibuk & Tidak & Sibuk & Sibuk & Tidak & Sibuk \\
\hline & & Pagi & Sibuk & Sore & Pagi & Sibuk & Sore \\
\hline & & \multicolumn{3}{|c|}{$\begin{array}{l}\text { (Terminal Muncang-Terminal } \\
\text { Pancasila) }\end{array}$} & \multicolumn{3}{|c|}{$\begin{array}{c}\text { (Terminal Pancasila-Terminal } \\
\text { Muncang) }\end{array}$} \\
\hline \multicolumn{8}{|c|}{ Weekend } \\
\hline $04 / 09 / 2019$ & Sabtu & 33,67 & 27,60 & 32,50 & 36,00 & 24,80 & 32,50 \\
\hline $05 / 09 / 2019$ & Minggu & 27,00 & 27,80 & 26,60 & 27,00 & 30,00 & 29,80 \\
\hline \multicolumn{2}{|c|}{ Rata-rata } & 30,33 & 27,70 & 29,55 & 31,50 & 27,40 & 31,15 \\
\hline \multicolumn{8}{|c|}{ Weekday } \\
\hline $08 / 09 / 2019$ & Selasa & 27,00 & 27,60 & 25,75 & 27,50 & 31,40 & 32,25 \\
\hline $09 / 09 / 2019$ & Rabu & 27,00 & 26,40 & 27,40 & 31,75 & 26,60 & 25,80 \\
\hline $10 / 09 / 2019$ & Kamis & 26,25 & 26,40 & 24,60 & 31,00 & 29,80 & 28,40 \\
\hline \multicolumn{2}{|c|}{ Rata-rata } & 26,75 & 26,80 & 25,92 & 30,08 & 29,27 & 28,82 \\
\hline
\end{tabular}

Sumber: Hasil Analisis, 2019

2. Waktu perjalanan (time trevel)

Waktu perjalanan adalah waktu yang diperlukan oleh kendaraan dari terminal asal menuju ke terminal tujuan dan kembali ke terminal asal (Direktorat
Jendral Perhubungan Darat,2002). Tabel 3 memperlihatkan waktu perjalanan angkot. Waktu siklus dapat dihitung dengan rumus : $\mathrm{CT}_{\mathrm{ABA}}=\left(\mathrm{T}_{\mathrm{AB}}+\mathrm{T}_{\mathrm{BA}}\right)+(\mathrm{sAB}+\mathrm{sBA})+$ $\left(\mathrm{TT}_{\mathrm{A}}+\mathrm{TT}_{\mathrm{B}}\right)$

Tabel 3. Waktu Perjalanan Angkot

\begin{tabular}{|c|l|c|c|c|c|c|c|}
\hline \multirow{2}{*}{} & \multicolumn{3}{|c|}{ Weekday } & \multicolumn{3}{c|}{ Weekend } \\
\cline { 3 - 8 } & $\begin{array}{c}\text { Jam } \\
\text { sibuk } \\
\text { pagi }\end{array}$ & $\begin{array}{c}\text { Jam } \\
\text { tidak } \\
\text { sibuk }\end{array}$ & $\begin{array}{c}\text { Jam } \\
\text { sibuk } \\
\text { sore }\end{array}$ & $\begin{array}{c}\text { Jam } \\
\text { sibuk } \\
\text { pagi }\end{array}$ & $\begin{array}{c}\text { Jam } \\
\text { tidak } \\
\text { sibuk }\end{array}$ & $\begin{array}{c}\text { Jam } \\
\text { sibuk } \\
\text { sore }\end{array}$ \\
\hline $\mathrm{T}_{\mathrm{AB}}$ & Menit & 26,75 & 26,80 & 25,92 & 30,33 & 27,70 & 29,55 \\
\hline $\mathrm{T}_{\mathrm{BA}}$ & Menit & 30,08 & 29,27 & 28,82 & 31,50 & 27,40 & 31,15 \\
\hline $\mathrm{sAB}$ & Menit & 1,34 & 1,34 & 1,30 & 1,52 & 1,39 & 1,48 \\
\hline $\mathrm{sBA}$ & Menit & 1,50 & 1,46 & 1,44 & 1,58 & 1,37 & 1,56 \\
\hline $\mathrm{TT}_{\mathrm{A}}$ & Menit & 2,68 & 2,68 & 2,59 & 3,03 & 2,77 & 2,96 \\
\hline $\mathrm{TT}_{\mathrm{B}}$ & Menit & 3,01 & 2,93 & 2,88 & 3,15 & 2,74 & 3,12 \\
\hline $\mathrm{CT}_{\mathrm{ABA}}$ & Menit & 65,36 & 64,48 & 62,94 & 71,11 & 63,37 & 69,81 \\
\hline $\mathrm{CT}_{\mathrm{ABA}}$ & Menit/km & 2,84 & 2,80 & 2,74 & 3,09 & 2,76 & 3,04 \\
\hline
\end{tabular}

Sumber: Hasil Analisis, 2019

3. Kecepatan perjalanan

Jarak tempuh untuk angkot line 03 tercatat $23 \mathrm{~km}$.

Tabel 4. Kecepatan Perjalanan Angkot

\begin{tabular}{|l|c|c|}
\hline & Weekday & Weekend \\
\hline Waktu Tempuh (s) rata-rata (jam) & 0,93 & 0,99 \\
\hline Jarak $(\mathrm{t})(\mathrm{km})$ & 23 & 23 \\
\hline Kecepatan $\left(V=\frac{S}{t}\right)$ & 24,7 & 23,3 \\
\hline
\end{tabular}

Sumber: Hasil Analisis, 2019 
Mar'atusholihah dan Ismaili

4. Faktor Muat (Load factor)

Faktor muat dihitung dengan menggunakan rumus :

$L F=\frac{J P}{k} \times 100 \%$ (2)

Tabel 5.Load factor

\begin{tabular}{|c|c|c|c|c|c|c|c|c|c|c|c|}
\hline Hari & \multirow[b]{2}{*}{$\mathrm{k}$} & Sabtu & Minggu & Selasa & Rabu & Kamis & Sabtu & Minggu & Selasa & Rabu & Kamis \\
\hline Jam & & \multicolumn{5}{|c|}{$\begin{array}{c}\text { Load factor Terminal Muncang - Terminal } \\
\text { Pancasila }(\%)\end{array}$} & \multicolumn{5}{|c|}{$\begin{array}{c}\text { Load factorTerminal Pancasila - Terminal } \\
\text { Muncang }(\%)\end{array}$} \\
\hline $05.00-05.59$ & 12 & 8,33 & 16,67 & 25,00 & 25,00 & 16,67 & 0,00 & 16,67 & 58,33 & 50,00 & 41,67 \\
\hline $06.00-06.59$ & 12 & 41,67 & 41,67 & 66,67 & 66,67 & 66,67 & 16,67 & 33,33 & 58,33 & 75,00 & 58,33 \\
\hline $07.00-07.59$ & 12 & 0,00 & 100,00 & 50,00 & 50,00 & 50,00 & 33,33 & 91,67 & 41,67 & 33,33 & 41,67 \\
\hline $08.00-08.59$ & 12 & 50,00 & 33,33 & 41,67 & 25,00 & 33,33 & 33,33 & 8,33 & 25,00 & 25,00 & 25,00 \\
\hline $09.00-09.59$ & 12 & 25,00 & 8,33 & 16,67 & 8,33 & 33,33 & 0,00 & 25,00 & 16,67 & 16,67 & 16,67 \\
\hline $10.00-10.59$ & 12 & 8,33 & 41,67 & 25,00 & 8,33 & 8,33 & 33,33 & 25,00 & 25,00 & 25,00 & 25,00 \\
\hline $11.00-11.59$ & 12 & 41,67 & 8,33 & 8,33 & 8,33 & 8,33 & 16,67 & 25,00 & 33,33 & 16,67 & 0,00 \\
\hline $12.00-12.59$ & 12 & 16,67 & 33,33 & 33,33 & 8,33 & 8,33 & 33,33 & 33,33 & 41,67 & 16,67 & 16,67 \\
\hline $13.00-13.59$ & 12 & 33,33 & 25,00 & 16,67 & 25,00 & 33,33 & 25,00 & 25,00 & 25,00 & 16,67 & 25,00 \\
\hline $14.00-14.59$ & 12 & 25,00 & 16,67 & 41,67 & 16,67 & 41,67 & 16,67 & 25,00 & 33,33 & 33,33 & 50,00 \\
\hline $15.00-15.59$ & 12 & 50,00 & 50,00 & 50,00 & 50,00 & 58,33 & 58,33 & 16,67 & 58,33 & 41,67 & 41,67 \\
\hline $16.00-16.59$ & 12 & 33,33 & 58,33 & 25,00 & 33,33 & 66,67 & 41,67 & 66,67 & 33,33 & 41,67 & 33,33 \\
\hline $17.00-17.59$ & 12 & 0,00 & 25,00 & 25,00 & 58,33 & 16,67 & 41,67 & 41,67 & 33,33 & 33,33 & 8,33 \\
\hline $18.00-18.59$ & 12 & 50,00 & 25,00 & 0,00 & 41,67 & 16,67 & 25,00 & 25,00 & 0,00 & 33,33 & 25,00 \\
\hline \multirow{2}{*}{\multicolumn{2}{|c|}{ Rata-rata }} & 27,38 & 34,52 & 30,36 & 30,36 & 32,74 & 31,25 & 26,79 & 32,74 & 34,52 & 32,74 \\
\hline & & end & 30,95 & \multicolumn{2}{|c|}{ day } & 31,15 & end & 29,76 & day & & 32,14 \\
\hline
\end{tabular}

Sumber: Hasil Analisis, 2019

Nilai Load factor dinyatakan memiliki kategori baik, bila kurang dari atau sama dengan nilai $80 \%$ pada jam sibuk dan nilai $70 \%$ diluar jam sibuk. Nilai rata-rata yang didapatkan 32,14\% kurang dari $70 \%$ maka nilai load factor
5. Waktu antara (Headway)

Headway berkaitan erat dengan frekuensi, jika nilai headway tinggi maka frekuensi rendah dan sebaliknya jika headway rendah maka frekuensi tinggi.bHubungan antara headway dan frekuensi adalah :

$H=\frac{1}{f}$

Sedangkan frekuensi adalah :

$f=\frac{P}{C . l f}$

Tabel 6.Headway

\begin{tabular}{|c|c|c|c|c|c|c|c|c|c|c|}
\hline & Sabtu & Minggu & Selasa & Rabu & Kamis & Sabtu & Minggu & Selasa & Rabu & Kamis \\
\cline { 2 - 12 } & \multicolumn{9}{|c|}{ Terminal Muncang - Terminal Pancasila } & \multicolumn{3}{c|}{ Terminal Pancasila - Terminal Muncang } \\
(menit)
\end{tabular}


Evaluasi Kebutuhan dan Kinerja Pelayanan Angkutan Umum Penumpang Kota Tasikmalaya

Lanjutan Tabel 6.

\begin{tabular}{|c|c|c|c|c|c|c|c|c|c|c|}
\hline $14.00-14.59$ & 3,2 & 3,5 & 3,0 & 3,1 & 3,1 & 3,0 & 3,3 & 3,5 & 3,8 & 2,6 \\
\hline $15.00-15.59$ & 4,0 & 3,2 & 2,9 & 2,8 & 3,0 & 5,1 & 3,7 & 3,3 & 3,0 & 3,0 \\
\hline $16.00-16.59$ & 3,4 & 3,1 & 2,3 & 3,3 & 2,4 & 3,6 & 4,4 & 3,1 & 3,4 & 2,7 \\
\hline $17.00-17.59$ & 4,3 & 3,5 & 3,6 & 3,5 & 3,7 & 4,2 & 5,5 & 4,2 & 3,3 & 3,4 \\
\hline Rata-rata & 3,6 & 3,3 & 3,3 & 3,2 & 3,2 & 3,7 & 3,7 & 3,5 & 3,4 & 3,2 \\
\hline
\end{tabular}

Sumber: Hasil Analisis, 2019

6. Waktu Tunggu

Untuk mendapatkan waktu tunggu, dapat

dihitung dengan menggunakan rumus $: W t=\frac{1}{2} x H$

Tabel 7.Waktu Tunggu

\begin{tabular}{|c|c|c|c|c|c|c|c|c|c|c|}
\hline & Sabtu & Minggu & Selasa & Rabu & Kamis & Sabtu & Minggu & Selasa & Rabu & Kamis \\
\cline { 2 - 12 } & \multicolumn{9}{|c|}{ Terminal Muncang - Terminal Pancasila } & \multicolumn{3}{c|}{ Terminal Pancasila - Terminal Muncang } \\
(menit)
\end{tabular}

Sumber: Hasil Analisis, 2019

7. Kebutuhan Angkutan Umum

Banyaknya armada yang dibutuhkan untuk memenuhi permintaan akan angkutan umum.

$N=\frac{C t}{H \cdot F a}$
Selain berdasarkan sirkulasi waktu, kebutuhan angkutan dapat dihitung berdasarkan pada priode waktu tertentu.

$N^{\prime}=N x \frac{W}{C T}$

Tabel 8. Kebutuhan Angkutan Umum

\begin{tabular}{|l|c|c|c|c|c|c|}
\hline & \multicolumn{3}{|c|}{ Weekday } & \multicolumn{3}{c|}{ Weekend } \\
\cline { 2 - 7 } & $\begin{array}{c}\text { Jam } \\
\text { sibuk } \\
\text { pagi }\end{array}$ & $\begin{array}{c}\text { Jam } \\
\text { tidak } \\
\text { sibuk }\end{array}$ & $\begin{array}{c}\text { Jam } \\
\text { sibuk } \\
\text { sore }\end{array}$ & $\begin{array}{c}\text { Jam } \\
\text { sibuk } \\
\text { pagi }\end{array}$ & $\begin{array}{c}\text { Jam } \\
\text { tidak } \\
\text { sibuk }\end{array}$ & $\begin{array}{c}\text { Jam } \\
\text { sibuk } \\
\text { sore }\end{array}$ \\
\hline Headway (H) & 3,54 & 3,15 & 3,15 & 3,82 & 3,13 & 3,98 \\
\hline Waktu perjalanan (CT) & 65,36 & 64,48 & 62,94 & 71,11 & 63,37 & 69,81 \\
\hline kebutuhan angkutan per waktu siklus (N) & 18 & 20 & 20 & 19 & 20 & 18 \\
\hline $\begin{array}{l}\text { kebutuhan angkutan pada priode waktu } \\
\text { (N') }\end{array}$ & 85 & 95 & 57 & 79 & 96 & 45 \\
\hline Rata-rata & \multicolumn{7}{|c|}{79} & & 73 & \\
\hline
\end{tabular}

Sumber: Hasil Analisis, 2019 
Mar'atusholihah dan Ismaili

\section{Uji Validasi Dan Reliabitas}

Pengujian Validitas dan reliabilitas dilakukan dengan menggunakan bantuan Microdoft Excel.Nilai dari r tabel merupakan batas kritis dari suatu atribut dianggap valid.Untuk dapat mengetahui nilai $r$ tabel sebelumnya dapat kita tentukan taraf signifikasi yang
dikehendaki.Taraf signifikasi adalah nilai toleransi dari suatu kesalahan. Nilai dari taraf signifikasi berupa $0,1 \% ; 0,5 ; 0,01 \%$ dll. Hasil uji validitas dan reliabilitas terlampir dalam Tabel 9 dan Tabel 10.

Tabel 9. Hasil Uji Validitas

\begin{tabular}{|l|c|c|c|c|}
\hline \multirow{2}{*}{ No } & \multicolumn{2}{|c|}{ r hitung } & \multirow{2}{*}{ r tabel } & \multirow{2}{*}{ Validitas } \\
\cline { 2 - 3 } & Kepuasan & Kepentingan & & \\
\hline 1. & 0,262 & 0,633 & 0,2565 & Valid \\
\hline 2. & 0,532 & 0,471 & 0,2565 & Valid \\
\hline 3. & 0,454 & 0,676 & 0,2565 & Valid \\
\hline 4. & 0,258 & 0,655 & 0,2565 & Valid \\
\hline 5. & 0,477 & 0,670 & 0,2565 & Valid \\
\hline 6. & 0,539 & 0,777 & 0,2565 & Valid \\
\hline 7. & 0,332 & 0,554 & 0,2565 & Valid \\
\hline 8. & 0,349 & 0,373 & 0,2565 & Valid \\
\hline 9. & 0,353 & 0,317 & 0,2565 & Valid \\
\hline 10. & 0,281 & 0,300 & 0,2565 & Valid \\
\hline 11. & 0,332 & 0,265 & 0,2565 & Valid \\
\hline 12. & 0,406 & 0,535 & 0,2565 & Valid \\
\hline 13. & 0,388 & 0,639 & 0,2565 & Valid \\
\hline 14. & 0,330 & 0,647 & 0,2565 & Valid \\
\hline 15. & 0,458 & 0,606 & 0,2565 & Valid \\
\hline 16. & 0,602 & 0,702 & 0,2565 & Valid \\
\hline 17. & 0,699 & 0,776 & 0,2565 & Valid \\
\hline 18. & 0,607 & 0,781 & 0,2565 & Valid \\
\hline 19. & 0,539 & 0,734 & 0,2565 & Valid \\
\hline
\end{tabular}

Sumber: Hasil Analisis, 2019

Tabel 10.Hasil Uji Reliabilitas

\begin{tabular}{|c|c|c|}
\hline Item pertanyaan $(\mathrm{k})$ & kepuasan $\left(\sigma_{b}^{a}\right)$ & kepentingan $\left(\sigma_{b}^{a}\right)$ \\
\hline 1 & 0,540 & 0,567 \\
\hline 2 & 0,687 & 0,717 \\
\hline 3 & 0,814 & 0,825 \\
\hline 4 & 0,696 & 0,924 \\
\hline 5 & 0,705 & 0,748 \\
\hline 6 & 0,983 & 0,573 \\
\hline 7 & 1,027 & 0,660 \\
\hline 8 & 0,735 & 0,492 \\
\hline 9 & 0,697 & 0,475 \\
\hline 10 & 0,667 & 0,521 \\
\hline 11 & 0,715 & 0,759 \\
\hline
\end{tabular}


Evaluasi Kebutuhan dan Kinerja Pelayanan Angkutan Umum Penumpang Kota Tasikmalaya

Lanjutan Tabel 10.

\begin{tabular}{|c|c|c|}
\hline 12 & 0,674 & 0,761 \\
\hline 13 & 0,775 & 0,745 \\
\hline 14 & 0,607 & 0,784 \\
\hline 15 & 0,553 & 0,768 \\
\hline 16 & 0,846 & 0,660 \\
\hline 18 & 0,765 & 0,846 \\
\hline 19 & 0,713 & 0,708 \\
\hline Harga varian item $\left(\sum \sigma_{b}^{a}\right)$ & 0,919 & 0,794 \\
\hline Harga varian total $\left(\sigma^{2 t}\right)$ & 14,118 & 13,328 \\
\hline
\end{tabular}

Sumber: Hasil Analisis, 2019

\section{Analisis Kepuasan Pelanggan}

Kepuasan adalah suatu kondisi dimana keinginan dan atau harapan dipenuhi.Menurut kamus Bahasa Indonesia kepuasan dapat diartikan sebagai perasaan puas, rasa senang dan kelegaan seseorang terhadap suatu produk atau jasa yang didapatkannya.

\section{PendekatanImportance-Performance Analysis(Ipa)}

1. Mencari Tingkat Kesesuaian

Tingkat kesesuaian adalah hasil perbandingan skor kinerja dengan skor kepentingan. Untuk mengetahui tingkat kesesuaian pada suatu penyedia jasa, dilakukan analisis antara kepentingan dan pelayanan riil yang diwakilkan oleh huruf $\mathrm{Y}$ dan $\mathrm{X}$, dimana $\mathrm{X}$ merupakan tingkat kinerja penyedia jasa, sedangkan $\mathrm{Y}$ merupakan tingkat kepentingan pwngguna jasa. Adapun rumus yang digunakan adalah:

$T k i=\frac{X i}{Y i} \times 100 \%$

Sumbu mendatar (X) akan diisi oleh skor tingkat kinerja, sedangkan sumbu tegak (Y) akan diisi oleh skor tingkat kepentingan. Dalam penyederhanaan rumus, maka untuk setiap atribut yang mempengaruhi kepuasan konsumen dapat diketahui dengan rumus:

$\bar{X}=\frac{\Sigma X i}{n}, \quad \bar{Y}=\frac{\Sigma Y i}{n}$

Diagram kartesius digunakan untuk mengetahui indikator jasa pelayanan yang memuaskan atau tidak memuaskan konsumen. Rumus yang digunakan adalah:

$\overline{\bar{X}}=\frac{\sum_{i=1}^{n} \bar{X}}{k}, \quad \overline{\bar{Y}}=\frac{\sum_{i=1}^{n} \bar{Y}}{k}$

Tabel 11. Skor Penilaian Kinerja Angkutan Umum

\begin{tabular}{|c|c|c|c|c|c|c|c|c|c|c|}
\hline No & Indikator & Atribut & SP & $\mathrm{P}$ & $\mathrm{N}$ & $\mathrm{KP}$ & $\mathrm{TP}$ & $\mathrm{n}$ & $\mathrm{X}$ & $\bar{X}$ \\
\hline \multirow{2}{*}{1.} & \multirow{2}{*}{ Keamanan } & $\mathrm{X} 1$ & 4 & 24 & 55 & 17 & 0 & 100 & 315 & 3,15 \\
\hline & & $\mathrm{X} 2$ & 3 & 35 & 43 & 17 & 2 & 100 & 320 & 3,20 \\
\hline \multirow{2}{*}{2.} & \multirow{2}{*}{ Keselamatan } & X3 & 2 & 15 & 44 & 30 & 9 & 100 & 271 & 2,71 \\
\hline & & $\mathrm{X} 4$ & 0 & 5 & 25 & 43 & 27 & 100 & 208 & 2,08 \\
\hline \multirow{2}{*}{3.} & \multirow{2}{*}{ Kenyamanan } & $\mathrm{X} 5$ & 4 & 26 & 50 & 17 & 3 & 100 & 311 & 3,11 \\
\hline & & X6 & 6 & 11 & 44 & 33 & 6 & 100 & 278 & 2,78 \\
\hline 4. & Keterjangkauan & $\mathrm{X7}$ & 13 & 28 & 43 & 12 & 4 & 100 & 334 & 3,34 \\
\hline 6. & Keteraturan & $\mathrm{X} 8$ & 1 & 7 & 33 & 44 & 15 & 100 & 235 & 2,35 \\
\hline \multirow{4}{*}{5.} & \multirow{4}{*}{ Kaandalan } & $\mathrm{X} 9$ & 1 & 9 & 38 & 41 & 11 & 100 & 248 & 2,48 \\
\hline & & $\mathrm{X} 10$ & 2 & 15 & 48 & 30 & 5 & 100 & 279 & 2,79 \\
\hline & & $\mathrm{X} 11$ & 2 & 16 & 50 & 25 & 7 & 100 & 281 & 2,81 \\
\hline & & $\mathrm{X} 12$ & 1 & 18 & 43 & 35 & 3 & 100 & 279 & 2,79 \\
\hline
\end{tabular}


Mar'atusholihah dan Ismaili

Lanjutan Tabel 11.

\begin{tabular}{|c|c|c|c|c|c|c|c|c|c|c|}
\hline \multirow{2}{*}{7.} & \multirow{2}{*}{ Daya Tanggap } & $\mathrm{X} 13$ & 2 & 19 & 38 & 36 & 5 & 100 & 277 & 2,77 \\
\hline & & $\mathrm{X} 14$ & 2 & 10 & 47 & 37 & 4 & 100 & 269 & 2,69 \\
\hline \multirow{3}{*}{8.} & \multirow{3}{*}{ Jaminan } & $\mathrm{X} 15$ & 1 & 17 & 53 & 26 & 3 & 100 & 287 & 2,87 \\
\hline & & $\mathrm{X} 16$ & 1 & 19 & 39 & 31 & 10 & 100 & 270 & 2,70 \\
\hline & & $\mathrm{X} 17$ & 1 & 18 & 42 & 30 & 9 & 100 & 272 & 2,72 \\
\hline 9. & Empati & $\mathrm{X} 18$ & 1 & 19 & 44 & 31 & 5 & 100 & 280 & 2,80 \\
\hline 10. & Berwujud & $\mathrm{X} 19$ & 2 & 19 & 37 & 33 & 9 & 100 & 272 & 2,72 \\
\hline \multicolumn{8}{|c|}{ Total } & 100 & 5286 & 52,9 \\
\hline & $\mathrm{k}=$ & 19 & & & & & & & $\overline{\bar{X}}=$ & 2,78 \\
\hline
\end{tabular}

Sumber: Hasil Analisis, 2019

Tabel 12. Skor Penilaian Kepentingan Pelanggan

\begin{tabular}{|c|c|c|c|c|c|c|c|c|c|c|}
\hline No & Indikator & Atribut & SP & $\mathrm{P}$ & $\mathrm{N}$ & KP & TP & $\mathrm{n}$ & Y & $\bar{Y}$ \\
\hline \multirow{2}{*}{1.} & \multirow{2}{*}{ Keamanan } & $\mathrm{Y} 1$ & 50 & 34 & 16 & 0 & 0 & 100 & 434 & 4,34 \\
\hline & & $\mathrm{Y} 2$ & 24 & 47 & 24 & 4 & 1 & 100 & 389 & 3,89 \\
\hline \multirow{2}{*}{2.} & \multirow{2}{*}{ Keselamatan } & $\mathrm{Y} 3$ & 52 & 23 & 22 & 3 & 0 & 100 & 424 & 4,24 \\
\hline & & Y4 & 45 & 29 & 20 & 5 & 1 & 100 & 412 & 4,12 \\
\hline \multirow{2}{*}{3.} & \multirow{2}{*}{ Kenyamanan } & Y5 & 40 & 39 & 16 & 5 & 0 & 100 & 414 & 4,14 \\
\hline & & Y6 & 61 & 23 & 16 & 0 & 0 & 100 & 445 & 4,45 \\
\hline 4. & Keterjangkauan & Y7 & 25 & 45 & 26 & 4 & 0 & 100 & 391 & 3,91 \\
\hline 6. & Keteraturan & Y8 & 48 & 39 & 13 & 0 & 0 & 100 & 435 & 4,35 \\
\hline \multirow{4}{*}{5.} & \multirow{4}{*}{ Kaandalan } & Y9 & 48 & 40 & 12 & 0 & 0 & 100 & 436 & 4,36 \\
\hline & & Y10 & 51 & 37 & 11 & 1 & 0 & 100 & 438 & 4,38 \\
\hline & & Y11 & 45 & 34 & 18 & 2 & 1 & 100 & 420 & 4,2 \\
\hline & & Y12 & 27 & 44 & 24 & 4 & 1 & 100 & 392 & 3,92 \\
\hline \multirow{2}{*}{7.} & \multirow{2}{*}{ Daya Tanggap } & Y13 & 40 & 35 & 22 & 3 & 0 & 100 & 412 & 4,12 \\
\hline & & Y14 & 31 & 37 & 27 & 5 & 0 & 100 & 394 & 3,94 \\
\hline \multirow{3}{*}{8.} & \multirow{3}{*}{ Jaminan } & Y15 & 35 & 33 & 29 & 3 & 0 & 100 & 400 & 4 \\
\hline & & Y16 & 55 & 29 & 15 & 0 & 1 & 100 & 437 & 4,37 \\
\hline & & Y17 & 54 & 24 & 17 & 5 & 0 & 100 & 427 & 4,27 \\
\hline 9. & Empati & Y18 & 55 & 25 & 18 & 2 & 0 & 100 & 433 & 4,33 \\
\hline 10. & Berwujud & Y19 & 48 & 29 & 19 & 4 & 0 & 100 & 421 & 4,21 \\
\hline \multicolumn{7}{|c|}{ Total } & & 100 & 7954 & 79,5 \\
\hline & $\mathrm{k}=$ & 19 & & & & & & & $\overline{\bar{Y}}=$ & 4,19 \\
\hline
\end{tabular}

Sumber: Hasil Analisis, 2019

Tabel 13. Tingkat Kesesuaian (Tki)

\begin{tabular}{|l|l|c|c|c|c|c|}
\hline \multirow{2}{*}{ No } & \multicolumn{1}{|c|}{ Indikator } & Atribut & $\mathrm{X}$ & $\mathrm{Y}$ & $\begin{array}{c}\text { Tingkat Kesesuaian } \\
(\%)(\mathrm{Tki})\end{array}$ & $\begin{array}{c}\text { Tingkat } \\
\text { Ketidaksesuaian (\%) }\end{array}$ \\
\hline \multirow{2}{*}{1.} & \multirow{2}{*}{ Keamanan } & $\mathrm{A} 1$ & 315 & 434 & 72,58 & 27,42 \\
\cline { 3 - 7 } & & $\mathrm{A} 2$ & 320 & 389 & 82,26 & 17,74 \\
\hline \multirow{2}{*}{2.} & \multirow{2}{*}{ Keselamatan } & $\mathrm{A} 3$ & 271 & 424 & 63,92 & 36,08 \\
\cline { 3 - 7 } & & $\mathrm{A} 4$ & 208 & 412 & 50,49 & 49,51 \\
\hline \multirow{2}{*}{3.} & \multirow{2}{*}{ Kenyamanan } & $\mathrm{A} 5$ & 311 & 414 & 75,12 & 24,88 \\
\cline { 3 - 7 } & & $\mathrm{A} 6$ & 278 & 445 & 62,47 & 37,53 \\
\hline 4. & Keterjangkauan & $\mathrm{A} 7$ & 334 & 391 & 85,42 & 14,58 \\
\hline 6. & Keteraturan & $\mathrm{A} 8$ & 235 & 435 & 54,02 & 45,98 \\
\hline
\end{tabular}


Evaluasi Kebutuhan dan Kinerja Pelayanan Angkutan Umum Penumpang Kota Tasikmalaya

Lanjutan Tabel 13.

\begin{tabular}{|l|l|l|l|l|l|l|}
\hline \multirow{3}{*}{5.} & \multirow{3}{*}{ Kaandalan } & A9 & 248 & 436 & 56,88 & 43,12 \\
\cline { 3 - 7 } & & $\mathrm{A} 10$ & 279 & 438 & 63,70 & 36,30 \\
\cline { 3 - 7 } & & $\mathrm{A} 11$ & 281 & 420 & 66,90 & 33,10 \\
\cline { 3 - 7 } & $\mathrm{A} 12$ & 279 & 392 & 71,17 & 28,83 \\
\hline \multirow{2}{*}{7.} & \multirow{2}{*}{ Daya Tanggap } & $\mathrm{A} 13$ & 277 & 412 & 67,23 & 32,77 \\
\hline \multirow{3}{*}{8.} & \multirow{3}{*}{ Jaminan } & $\mathrm{A} 14$ & 269 & 394 & 68,27 & 31,73 \\
\hline & & $\mathrm{A} 15$ & 287 & 400 & 71,75 & 28,25 \\
\hline & & $\mathrm{A} 16$ & 270 & 437 & 61,78 & 38,22 \\
\hline & & $\mathrm{A} 17$ & 272 & 427 & 63,70 & 36,30 \\
\hline 10. & Empati & $\mathrm{A} 18$ & 280 & 433 & 64,67 & 35,33 \\
\hline
\end{tabular}

Sumber: Hasil Analisis, 2019

Nilai rata-rata dari hasil tingkat kesesuaian diatas, yaitu sebesar $66,68 \% \approx 67 \%$ yang kemudian nilai ini dijadikan dasar acuan untuk mengambil keputusan sebagai berikut: a. Bila TK < 67\% maka dilakukan perbaikan / action (A)

b. Bila TK $\geq 67 \%$ maka dilakukan usaha untuk mempertahankan prestasi/hold $(\mathrm{H})$

Tabel 14. Tabel Keputusan Hold \& Action

\begin{tabular}{|c|c|c|c|}
\hline Atribut & $\begin{array}{c}\text { Tingkat } \\
\text { Kesesuaian }(\%)\end{array}$ & $\begin{array}{c}\text { Batasan Tingkat } \\
\text { Kesesuaian }(\%)\end{array}$ & $\begin{array}{c}\text { Keputusan Hold } \\
\text { atau Action }\end{array}$ \\
\hline A1 & 72,58 & 67 & Hold \\
\hline A2 & 82,26 & 67 & Hold \\
\hline A3 & 63,92 & 67 & Action \\
\hline A4 & 50,49 & 67 & Hold \\
\hline A5 & 75,12 & 67 & Action \\
\hline A6 & 62,47 & 67 & Hold \\
\hline A7 & 85,42 & 67 & Action \\
\hline A8 & 54,02 & 67 & Action \\
\hline A9 & 56,88 & 67 & Action \\
\hline A10 & 63,70 & 67 & Hold \\
\hline A11 & 66,90 & 67 & Hold \\
\hline A12 & 71,17 & 67 & Hold \\
\hline A13 & 67,23 & 67 & Hold \\
\hline A14 & 68,27 & 67 & Action \\
\hline A15 & 71,75 & 67 & Action \\
\hline A16 & 61,78 & 67 & Action \\
\hline A17 & 63,70 & 67 & Action \\
\hline A18 & 64,67 & 67 & 67 \\
\hline A19 & 64,61 & & \\
\hline
\end{tabular}

Sumber: Hasil Analisis, 2019

2. Diagram Kartesius

Diagram kartesius digunakan untuk memetakan atibut-atribut kualitas jasa pelayanan pendidikan yang telah dianalisis untuk menentukan diagram kartesius dapat menggunakan data rata-rata nilai $X$ dan Y.Didapatkan hasil seperti gambar dibawah ini : 


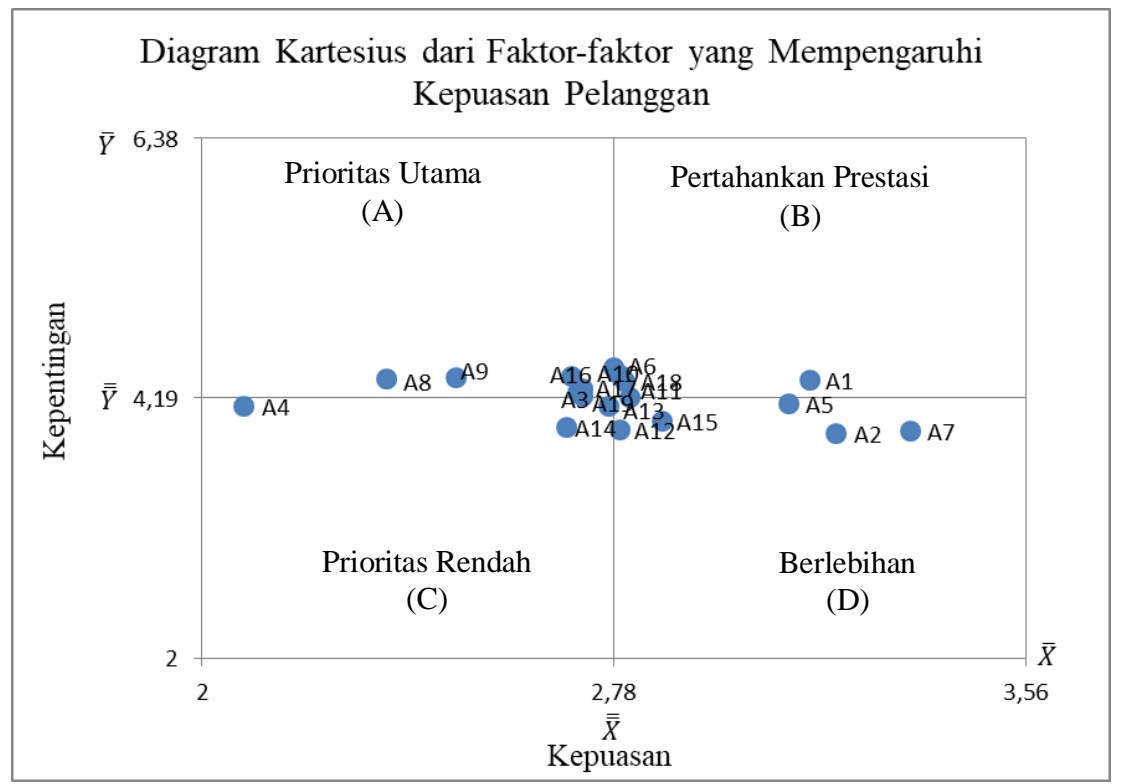

Gambar 2. Diagram Kartesius

(Sumber: Hasil Analisis, 2019)

Prioritas utama (Dianggap penting tetapi kinerjanya mengecewakan, perlu ditingkatkan)

a) $\mathrm{A} 3=$ Pengemudi memenuhi Standar Oprasional Prosedur (SOP) pengoprasian kendaraan

b) A6 = Mengutamakan keselamatan dan kelancaran lalu lintas

c) $\mathrm{A} 8=$ Ketepatan waktu datang dan pergi angkot.

d) A9 = Kecepatan dan waktu tempuh dalam angkot saat diperjalanan.

e) A16 = Kompeten dan disiplin saat mengemudikan angkot dan berlalu-lintas.

f) A17 = Rasa aman dan nyaman terhadap diri atau barang saat berada di dalam angkot

g) A19 = Kelayakan armada, kondisi angkot baik sarana maupun prasarana menyangkut kebersihan, kondisi mesin, keleluasaan tempat duduk.

Pertahankan prestasi (Dianggap penting dan kinerjanya memuaskan, perlu dipertahankan)

a) $\mathrm{A} 1$ = Kelengkapan identitas kendaraan dan awak kendaraan

b) $\mathrm{A} 10=$ Kemudahan mencapai tujuan dengan menggunakan angkot. c) A11 = Kemudahan untuk beralih rute dan trayek angkot.

d) A18 = Kepedulian pengemudi terhadap penumpang khusus (lansia, ibu hamil, difabel, dll)

Prioritas rendah (Dianggap kurang penting dan kurang memuaskan)

a) A4 = Tersedianya sarana dan prasarana penunjang seperti: peralatan keselamatan (alat pemadam api ringan, cadangan ban, sabuk keselamatan, dll), fasilitas kesehatan, fasilitas penyimpanan dan pemeliharaan kendaraan

b) $\mathrm{A} 13=$ Kesediaan pengemudi memberikan informasi kepada pengguna. Informasi berupa rute angkot, arah perjalanan, dll

c) $\mathrm{A} 14=$ Kecepatan dalam memberikan tanggapan atas pelayanan angkutan

Berlebihan (Dianggap kurang penting tetapi kinerjanya memuaskan dinilai berlebihan)

a) A2 = Lampu penerangan yang memadai, dan tersedianya lapisan kaca film untuk mengurangi cahaya matahari langsung

b) $\mathrm{A} 5=$ Mengangkut penumpang sesuai dengan kapasitas angkot 
Evaluasi Kebutuhan dan Kinerja Pelayanan Angkutan Umum Penumpang Kota Tasikmalaya

c) A7 = Kesesuaian tarif angkot dengan jarak yang di tempuh dan atau pelayanan yang diberikan

d) A12 = Jarak asal menuju halte atau tempat pemberhentian angkot

e) $\mathrm{A} 15$ = Sifat pengemudi (ramah, sopan, jujur,dll)

\section{Customer Satisfaction Index (CSI)}

Perhitungan CSI dilakukan sebagai berikut:

1. Weight Factor (WF)

$$
\mathrm{WF}=\frac{\text { MISi }}{\text { Total MIS }} \times 100 \%
$$

\section{Mean Importance Score}

$$
M I S=\frac{\sum_{i=1}^{n} Y i}{n}
$$

3. Menghitung Weighted score (WS)

$\mathrm{WS}=\operatorname{MSS} x \mathrm{WF}$

$$
(M S S)=\frac{\sum_{i=1}^{n} X i}{n}
$$

4. Menghitung Weighted Average (WA)

Dalam mencari nilai WA, dengan cara menjumlahkan semua Weight Score (WS).

5. Menghitung Customer Satisfaction Index (CSI)

$\mathrm{CSI}=\frac{W A}{H S} x 100 \%$

Tabel 15. Perhitungan Customer Satisfaction Index (CSI)

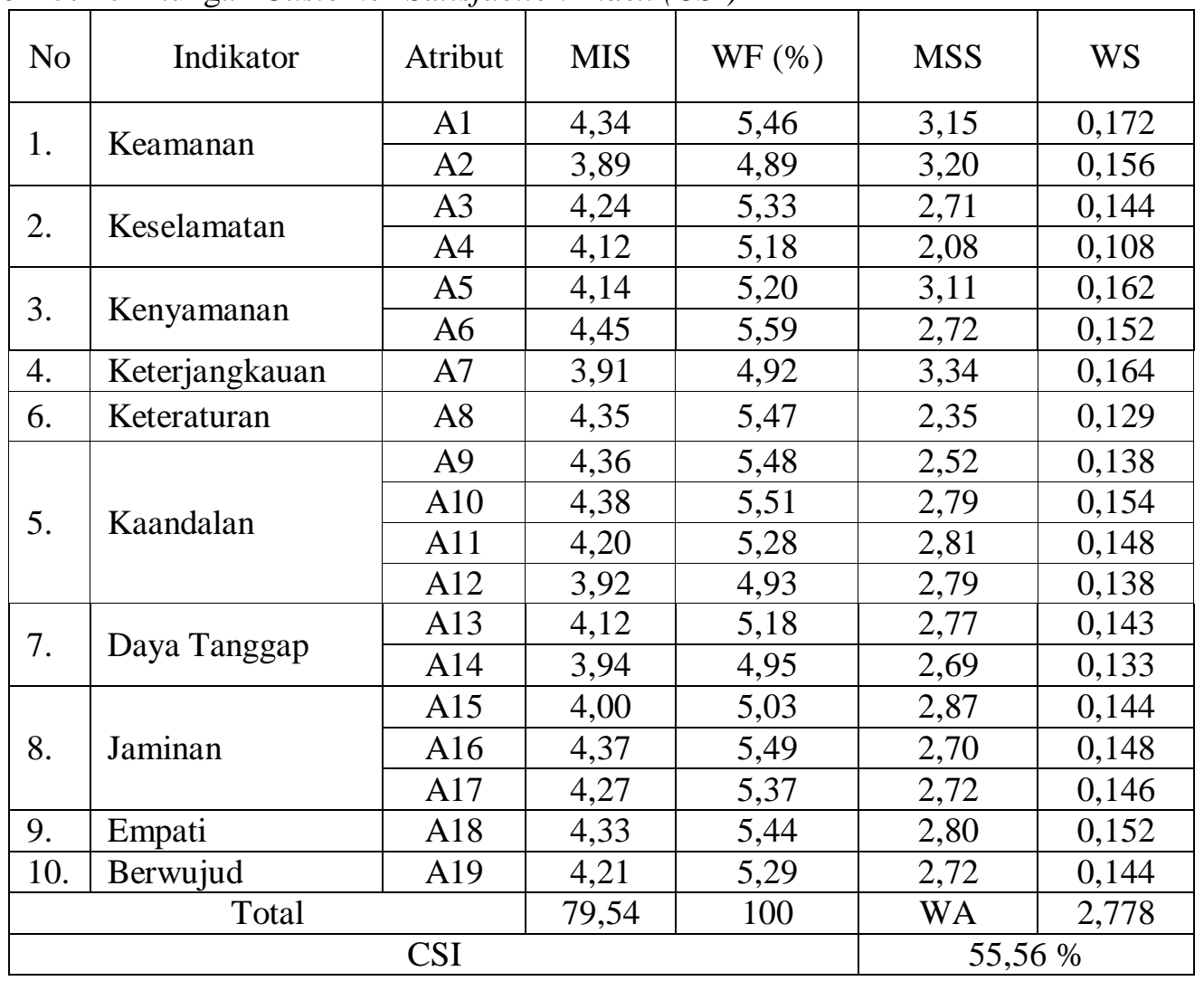

Sumber: Hasil Analisis, 2019

\section{KESIMPULAN}

Berdasarkan penelitian yang telah dilakukan maka dapat di ambil beberapa kesimpulan sebagai berikut:
1. Kinerja pelayanan angkutan umum berdasarkan keputusan Direktorat Jendral Perhubungan Darat tahun 2002 dinilai Baik. Dengan total nilai yang diperoleh sebanyak 26. 
Mar'atusholihah dan Ismaili

\begin{tabular}{|c|c|c|c|c|c|c|c|c|c|}
\hline \multirow{4}{*}{ No } & \multirow{4}{*}{ Indikator } & \multirow{4}{*}{ Satuan } & \multicolumn{3}{|c|}{ Nilai } & \multirow{4}{*}{$\begin{array}{c}\text { Hasil } \\
\text { weekday }\end{array}$} & \multirow{4}{*}{ Nilai } & \multirow{4}{*}{$\begin{array}{c}\text { Hasil } \\
\text { weekend }\end{array}$} & \multirow{4}{*}{ Nilai } \\
\hline & & & 1 & 2 & 3 & & & & \\
\hline & & & \multicolumn{3}{|c|}{ Kriteria } & & & & \\
\hline & & & Kurang & Sedang & Baik & & & & \\
\hline 1. & Rata-rata faktor muat pada jam sibuk & & $>1$ & $0,8-1$ & $<0,8$ & 0,367 & 3 & 0,319 & 3 \\
\hline 2. & Rata-rata faktor muat diluar jam sibuk & & $>1$ & $0,7-1$ & $<0,7$ & 0,191 & 3 & 0,266 & 3 \\
\hline 3. & Rata-rata kecepatan perjalanan & $\mathrm{km} / \mathrm{jam}$ & $<5$ & $5-10$ & $>10$ & 24,7 & 3 & 23,3 & 3 \\
\hline 4. & Rata-rata waktu antara / headway & menit & $>15$ & $10-15$ & $<10$ & 3,3 & 3 & 3,5 & 3 \\
\hline 5. & Rata-rata waktu perjalanan & menit $/ \mathrm{km}$ & $>12$ & $6-12$ & $<6$ & 2,79 & 3 & 2,96 & 3 \\
\hline 6. & Waktu pelayanan & jam & $<13$ & $13-15$ & $>15$ & $13-15$ & 2 & $13-15$ & 2 \\
\hline 7. & Frekuensi & $\mathrm{kend} / \mathrm{jam}$ & $<4$ & $4-6$ & $>6$ & 19,53 & 3 & 18,21 & 3 \\
\hline 8. & Jumlah kendaraan yang beroperasi & $\%$ & $<82$ & $82-100$ & $>100$ & 97 & 2 & 97 & 2 \\
\hline 9. & Rata-rata waktu tunggu penumpang & menit & $>30$ & $20-30$ & $<20$ & 1,8 & 3 & 1,6 & 3 \\
\hline \multirow[t]{2}{*}{10.} & Awal dan akhir waktu pelayanan. & & $05-18$ & $05-20$ & $05-22$ & $05-18$ & 1 & $05-18$ & 1 \\
\hline & & & & & & & 26 & & 26 \\
\hline
\end{tabular}

2. Faktor-faktor yang dapat berpengaruh terhadap penilaian kepuasan pelanggan diantaranya fakor keamanan, keselamatan, waktu dan kelayakan armada.

3. Kepuasan pelanggan terhadap angkutan umum berdasarkan pendekatan IPA dan penilaian CSI masuk ke dalam kriteria Cukup Baik dengan nilai CSI yang diperoleh $55,56 \%$ dalam range nilai $40 \%$ $<55,56 \leq 60 \%$.

\section{DAFTAR NOTASI}

$\mathrm{C}=$ kapasitas kendaraan (orang)

$\mathrm{CT}=$ Waktu sirkulasi dari A ke B kembali ke A (menit)

$f \quad=$ frekuensi

$\mathrm{fA}=$ Faktor ketersediaan kendaraan $(100 \%)$

$\mathrm{H}=$ Headway (menit)

$\mathrm{HS}=$ Highest scale

JP = Jumlah Penumpang (orang)

$\mathrm{k}=$ Banyaknya atribut

Lf = Load Factor

$\mathrm{n} \quad=$ jumlah responden

$\mathrm{N}$ = Jumlah armada yang dibutuhkan

$\mathrm{P} \quad=$ Jumlah penumpang perjam pada sesi terpadat (orang)

$\mathrm{S}=$ Deviasi waktu perjalanan

Tki = Tingkat kesesuaian responden.

$\mathrm{T}=$ Waktu perjalanan rata-rata

TT = Waktu henti kendaraan

$\mathrm{X}=$ Melambangkan kinerja/kepuasan

$\mathrm{Y}=$ Melambangkan kepentingan
$\overline{\bar{X}}=$ Rata-rata dari rata-rata bobot tingkat kinerja angkutan umum

$\overline{\bar{Y}}=$ Rata-rata dari rata-rata tingkat kepentingan pelanggan

$\bar{X}=$ Rata-rata tingkat penilaian kinerja angkutan umum

$\bar{Y}=$ Rata-rata tingkat penilaian kepentingan pelanggan

$\Sigma \mathrm{Xi}=$ Total skor penilaian kinerja angkutan umum

$\Sigma \mathrm{Yi}=$ Total skor penilaian kepentingan pelanggan

\section{DAFTAR PUSTAKA}

Morlok, E. K. 1985. Pengantar Teknik dan Perencanaan Transportasi. Jakarta: Erlangga

Republik Indonesia. 2002. Surat Keputusan Direktor Jenderal Perhubungan Darat Nomor SK.687/AJ.206/DRJD/2002 tentang Pedoman Teknis Penyelenggaraan Angkutan Penumpang Umum di Wilayah Perkotaan dalam Trayek Tetap dan Teratur. Direktorat Jenderal Perhubungan Darat. Jakarta

Supranto, J, 2006, Pengukuran Tingkat Kepuasan Pelanggan, Rineka Cipta, Jakarta. 